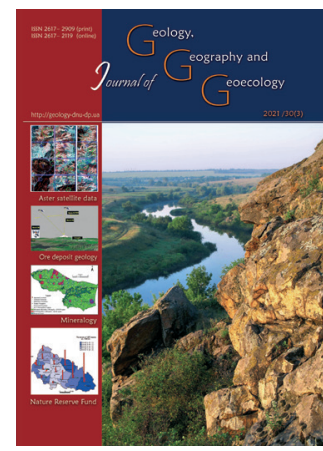

\section{Journal of Geology. Geography and Geoecology}

Journal home page: geology-dnu.dp.ua
ISSN 2617-2909 (print)

ISSN 2617-2119 (online)

Journ. Geol. Geograph. Geology, 30(3), 441-448.

doi: $10.15421 / 112140$

Hryniuk V. I., Arkhypova L. M., Korchemlyuk M. V.

Geol. Geograph. Geoecology, 30(3), 441-448

\title{
Investigation of buffer capacity of the recreational environmental through the self-purification of natural-technogenic hydroecosystems in the Carpathian region
}

\author{
Victoria I. Hryniuk ${ }^{1}$, Lyudmyla M. Arkhypova ${ }^{1}$, Marta V. Korchemlyuk ${ }^{2}$ \\ ${ }^{1}$ Institute of Natural Sciences and Tourism, Ivano-Frankivsk National Technical University of Oil and Gas, 76019, \\ Ivano-Frankivsk, Ukraine, e-mail:konsevich@ukr.net \\ ${ }^{2}$ Carpathian National Nature Park, Stusa str., 6, Yaremche, 78500, Ukraine
}

Received: 22.03.2021

Received in revised form: 13.04 .2021

Accepted: 29.04.2021

Abstract. The aim of research was to investigate the theoretical and practical aspects of the buffer capacity of the recreational environment of the Carpathian region of Ukraine through the improvement of self-purification assessment on the example of natural-technogenic hydroecosystems. Studies of the self-purification process were carried out on the example of the right tributaries of the river Svicha in the Carpathian region, which are water intakes of wastewater from the oil and gas industry enterprise of Ivano-Frankivsk region. The main factors influencing the natural process of self-purification of natural watercourses are determined. As a result, the indicator of wastewater dilution intensity was improved with the substantiation of the proposed coefficients, which depend on the value of the river flow velocity and water temperature. A scale for assessing surface waters has been developed, that allows to determine the degree of natural self-purification of water from pollutants. Based on the results of the analysis of selected water samples, the pattern of self-purification of natural watercourses from oil products is obtained, which will allow to make forecast maps of the buffer capacity of the recreational environment of the Carpathian region. A regression analysis was performed, which proves the relationship between the content of petroleum products and the distance of their distribution from the source of pollution in the Lushchava River. Fisher's F-test was used to check the significance of the dependence. The reliability of the relationship between the indicators is confirmed by the coefficient of determination $\left(D=r^{2}\right)$, which is 0.96 . Summarizing the results of the study the scale of estimation of natural self-purification of surface waters from pollutants depending on the calculated indicator of wastewater dilution intensity which's criteria are the accounting for speed of a river flow and a temperature mode is offered. When establishing the range of $n$ values, the average value of the calculated indicator of the intensity of wastewater dilution for the studied rivers, which is 4 , was taken into account. As a result, the proposed scale of assessment of natural self-purification of surface waters allows to determine the degree of self-purification of the right tributaries of the river Svicha, which is necessary for further forecasting of water pollution in the Carpathian region.

Ключові слова: recreational environment, hydroecosystem, degree of self- purification, dilution index

\section{Дослідження буферної здатності рекреаційного середовища через самоочищення природно- техногенних гідроекосистем в Карпатському регіоні}

\section{В. І. Гринюк ${ }^{1}$, Л. М. Архипова ${ }^{1}$, М. В. Корчемлюк ${ }^{2}$}

${ }^{1}$ Інститут природничих наук і туризму, Івано-Франківський національний технічний університет нафти $і$ газу, Івано-Франківськ, Украӥна, е-таil: konsevich@ukr.net

${ }^{2}$ Карпатський начіональний природний парк, м. Яремче, Івано-Франківська обл. Украйна

Анотація. Метою дослідження було дослідити теоретичні та практичні аспекти буферної ємності рекреаційного середовища Карпатського регіону України шляхом вдосконалення оцінки самоочищення природно-техногенних гідроекосистем. Дослідження процесу самоочищення проводилось на прикладі правих приток річки Свіча в Карпатському регіоні, які є водозаборами стічних вод підприємства нафтогазової промисловості Івано-Франківської області. Визначено основні фактори, що впливають на природний процес самоочищення природних водотоків. В результаті, показник інтенсивності розбавлення стічних вод був покращений обгрунтуванням запропонованих коефіцієнтів, які залежать від величини швидкості течії річки та температури води. За результатами аналізу відібраних проб води отримано закономірність самоочищення природних водотоків від нафтопродуктів, що дозволить складати прогнозні карти буферної ємності рекреаційного середовища Карпатського регіону. Проведено регресійний аналіз, який доводить взаємозв'язок між вмістом нафтопродуктів та відстанню їх розподілу від джерела забруднення в річці Лущаві. F-тест Фішера використовувався для перевірки значимості залежності. Надійність взаємозв'язку між показниками підтверджується коефіцієнтом детермінації $\left(\mathrm{D}=\mathrm{r}^{2}\right)$, який дорівнює 0,96 . Узагальнюючи результати дослідження, пропонується шкала оцінки природного самоочищення поверхневих вод від забруднюючих речовин залежно від розрахункового показника 
інтенсивності розбавлення стічних вод, критеріями яких є врахування швидкості течії річки та температурного режиму. При встановленні діапазону значень $\mathrm{n}$ було враховано середнє значення розрахункового показника інтенсивності розведення стічних вод для досліджуваних річок, яке становить 4. У підсумку, запропонована шкала оцінки природного самоочищення поверхневих вод дозволяє визначити ступінь самоочищення правих приток річки Свічі, який необхідний для подальшого прогнозування рівня забрудненості водних об'єктів Карпатського регіону.

Ключові слова: рекреаційне середовище, гідроекосистема, ступінь самоочищення, показник розбавлення.

\section{Introduction.}

The concept of buffering capacity of hydroecosystems logically follows from their essence and features (Prykhodko et al, 2020, Kresić, Stevanović, 2010). Hydroecosystems have evolved over millions of years, and cyclical exchange is maintained both internally and externally as a component of larger ecosystems (Khilchevskyi et al, 2018). Ecological cycles are characterized by continuous fluctuations of their variable characteristics (Mandryk et al, 2017). When changing conditions disrupt any connection in the hydroecosystem, the whole cycle behaves as one self-regulating system with feedback, and soon, the situation returns to equilibrium (Rajchel, Czop 2013). Since such disturbances occur all the time, the variables of hydroecosystems fluctuate continuously. In a natural hydroecosystem, all ecological fluctuations occur within acceptable limits of homeostasis (restoration of equilibrium) (Bouman, 2014). In a man-made system there is a danger that with the fluctuations beyond acceptable limits, the system will not be able to compensate for the disturbance (Shmandiy et al, 2017). The scope of permissible fluctuations of ecological cycles is the flexibility of the hydroecosystem (Shkitsa et al, 2020). Lack of flexibility is a lack of "health" of the hydroecosystem, which means the potential of the buffer capacity or hydroecological potential (Eigen, Schuster, 2012).

The ecological sustainability of the hydroecosystem depends on the limited resource base (quantitative and qualitative potential) and on its diversification (diversity), that is, on the magnitude. The more diverse the hydroecosystem, the more diverse the relationship it is able to maintain if one connection is broken (Chelmicki et al,2011).

It is obvious that the hydroecological potential is restored due to the variable processes of the cycle of matter and the processes of self-purification (Karpinski et al, 2018,). Hydroecological potential of the local hydroecosystem to assess the impact of man-made activities is extremely important, because the processes at this level are a continuous course of environmental disturbance by human economic activity (Kinash et al, 2019, Simkiv et al, 2021). Variable components at this level are highly dependent on climatic, physicalgeographical and other environmental conditions (Staśko, Buczyński, 2018). In addition, local discharges into water bodies are the anomalies for the hydroecosystem.
In resource terms, hydroecological potential means the part of water resources that can be used by the national economic complex while maintaining environmental safety and balanced water use in natural and man-made hydroecosystems (i.e. man-made activities ensure sustainable development while minimizing disturbances of hydroecosystems to the limit).

Thus, the following question arises: at what level balanced water should be considered? There is no doubt that specific quantitative parameters of the balance can be obtained by identifying hydroecosystems at different levels of detalization. One can agree with the authors (Odnorih et al, 2020) of the opinion that humanity, as a whole, consumes an insignificant share of hydrosphere resources (the available volume of fresh water used by mankind is about $0.5 \%$ ), without changing the volume of the water cycle in nature. The duration of the biological cycle of the main, most common heavy metals in the geological history is negligible and is in the range of 5-100 years. That is why human activity within the hydrosphere over a 100-year time interval can be considered as part of a balanced closed cycle. In this case, the mechanism of inertia of metabolic processes that are continuous in the hydrosphere, only delay the process of restoring quality, but do not change it (Stevens et al, 2011).

The aim of research was investigat the theoretical and practical aspects of the buffer capacity of the recreational environment of the Carpathian region of Ukraine through the improvement of self-purification assessment on the example of natural-technogenic hydroecosystems.

\section{Materials and methods.}

Further studies of the self-purification process were carried out on the example of the right tributaries of the river Svicha in the Carpathian region, which are water intakes of wastewater from the oil and gas industry enterprise OGPD "Dolynanaftogaz" Ivano-Frankivsk region.

After analyzing the statistical reports of the enterprise on hydrochemical monitoring of surface waters, wastewater contains the following chemicals: chlorides, nitrates, nitrites, ammonium nitrogen, ammonium salt, sulfates, phosphates, $\mathrm{BOD}_{5}$, suspended solids, petroleum products. Most of the wastewater contains organic substances, as the quality of wastewater is formed from industrial, domestic and rainwater of auxiliary structural units of OPGD "Dolynanaftogaz". 
After the discharge of return wastewater of the enterprise into surface waters, first there is a process of mixing and dilution of polluted wastewater with river water. If we study the concentration of a specific pollutant in wastewater and directly in river water, their values usually differ. The rate of reduction of the impurity content in the water depends on the concentration of the pollutant in the wastewater.

The indicator of wastewater dilution intensity is determined with the formula (Karpets, 2014):

$$
n=\frac{\mathrm{Co}-\mathrm{C} w}{\mathrm{C}-\mathrm{C} w}
$$

where $C_{0}$ is the concentration of pollutant contained in wastewater discharged into natural streams, $\mathrm{mg} / \mathrm{dm}^{3}$; $C w$ and $C$ - the concentration of pollutants in the reservoir before and after release, respectively, $\mathrm{mg} / \mathrm{dm}^{3}$.

The study of the database of ecological monitoring of surface waters revealed exceeding the maximal allowable concentration for nitrogen-containing compounds, chlorides, $\mathrm{BOD}_{5}$ (biochemical oxygen demand for 5 days). Therefore, to track the dynamics of changes in chemicals in the background and $500 \mathrm{~m}$ below the discharge of wastewater, calculations were performed to determine the intensity of dilution of wastewater specifically for those chemical compounds that exceed the standard of maximum permissible concentration (MPC) (Gomelya et al, 2019).

Because the content of petroleum products in the water of the right tributaries of the river Svicha is within the norm (not more than $0.05 \mathrm{mg} / \mathrm{dm}^{3}$ ), the dilution intensity for petroleum products was not calculated.

\section{Results.}

The average value of concentrations of chemical elements in the discharge of wastewater into natural watercourses, as well as $500 \mathrm{~m}$ above and $500 \mathrm{~m}$ below the discharge No. 1, 2, 3, 4 was calculated on the basis of quarterly environmental surface water monitoring data (Hryniuk V. I., 2018).

During the calculation of the water dilution intensity index, negative values were found in the Turianka and Lushchava rivers, which indicates that the value of the pollutant concentration exceeded $500 \mathrm{~m}$ above the issues No 1; 3 (Table 1).

As a result, the average annual intensity of dilution of pollutants in the right tributaries of the river Svicha was calculated, which characterizes how the concentration of these substances in the calculated line of the river decreased relative to its concentration in wastewater (Table 1). In this case, the highest average annual intensity of wastewater dilution for the river Sadzhava (4.1), the lowest - for the river Turianka $(1,2)$.
Table 1. The average annual change in the intensity of dilution of pollutants in the right tributaries of the river Svicha

\begin{tabular}{|c|c|c|c|}
\hline Water body & r.Turianka & r.Sadzhava & r.Lushchava \\
\hline $\mathrm{Cl}^{-}$(chlorides) & 4.0 & 4.4 & 0.22 \\
\hline $\begin{array}{c}\mathrm{NH}_{4}^{+} \\
\text {Ammonium) }\end{array}$ & 1.1 & 2.7 & 8.4 \\
\hline $\begin{array}{c}\mathrm{NO}_{2} \\
\text { (Nitrite) }\end{array}$ & 0.4 & 1.4 & -0.28 \\
\hline $\begin{array}{c}\mathrm{BOD}_{5} \\
\text { (biochemical } \\
\text { oxygen } \\
\text { demand for 5 } \\
\text { days) }\end{array}$ & -0.9 & 9.3 & 0.7 \\
\hline $\begin{array}{c}\text { ammonium } \\
\text { nitrogen }\end{array}$ & 1.4 & 2.8 & 5.2 \\
\hline$n$ & 1.2 & 4.1 & 2.8 \\
\hline
\end{tabular}

The disadvantage of this indicator is that in its calculation only the concentrations of chemicals in wastewater and natural watercourses are taken into account. Other factors influencing the process of dilution of contaminated water are not considered.

The main factors that affect the intensity of surface water self-purification include: morphometric characteristics (flow velocity, river depth), hydrological regime, climatic conditions, relief, location of natural watercourses (geographical factor); condition of soils and vegetation; the impact of human activities (the presence of enterprises, unauthorized discharges of waste near natural watercourses).

Indicator of the intensity of dilution of wastewater is proposed to improve by taking into account hydrometeorological factors (Mandryk et al, 2020). The improved indicator differs in that coefficients are taken into account, which depend on the value of the river velocity and water temperature.

$$
n=\frac{\mathrm{Co}-\mathrm{C} w}{\mathrm{C}-\mathrm{C} w} \cdot k_{V} \cdot k_{t}
$$

де $k_{V}$ - the proposed coefficient, the value of which depends on the speed of the river;

$k_{t}$ - the proposed coefficient, the value of which depends on the water temperature.

The value of the coefficients is based on the calculations performed by the formulas:

$$
\begin{aligned}
k_{V} & =\frac{V}{V_{c}} \\
k_{t} & =\frac{t}{t_{c}}
\end{aligned}
$$

where $V$ - the specified speed of the river, $\mathrm{m} / \mathrm{s} ; V c-$ average velocity of the right tributaries of the river Svicha, $\mathrm{m} / \mathrm{s} ; t$ - specified water temperature, ${ }^{\circ} \mathrm{C}$;

$t_{c}$ - the average annual water temperature of the right tributaries of the river Svicha, ${ }^{\circ} \mathrm{C}$. 
The ranges were selected on the basis of the analysis of current velocities and average annual water temperature indicators for small and large rivers of Ukraine.

The chartes of dependence of $k_{v}$ on the flow velocity and $k_{t}$ on the average annual temperature have been created, provided that the average water flow velocity for the right tributaries of the river Svicha is $0.17 \mathrm{~m} / \mathrm{s}$, the average annual water temperature is $10{ }^{\circ} \mathrm{C}$ (Fig. 1).

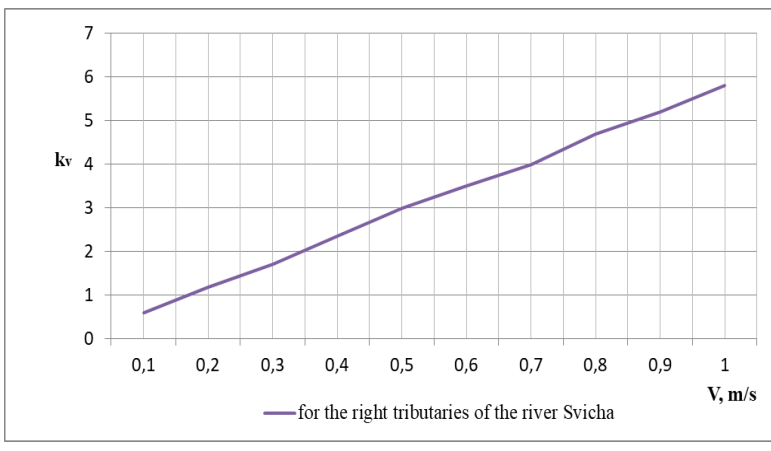

a)

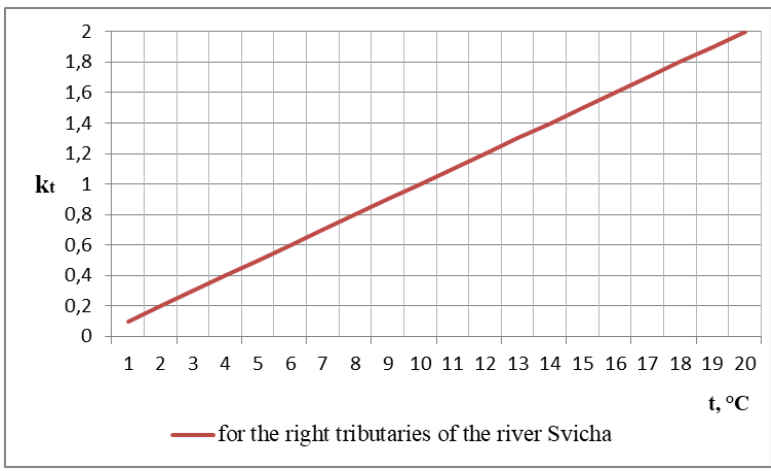

b)

Fig.1. Dependence of ${ }^{k}$ on the flow velocity (a); ${ }^{k_{t}}$ from the average annual water temperature of the right tributaries of the river Svicha (b)

Based on the obtained diargams of the dependences of the proposed coefficients on hydrometeorological parameters, the values of $k_{V}$ and $k_{t}$ for the rivers Turianka, Sadzhava and Lushchava were obtained: if $\mathrm{V}=0.17 \mathrm{~m} / \mathrm{s}$, then $k_{V=1}$ (for the river Turianka); if $\mathrm{V}=0.24 \mathrm{~m} / \mathrm{s}$, then $k_{V}=1.4$ (for the river Sadzhava); if $\mathrm{V}=0.1 \mathrm{~m} / \mathrm{s}$, then $k_{V}=0.7$; (for the river Lushchava); if $\mathrm{t}=10{ }^{\circ} \mathrm{C} \mathrm{m} / \mathrm{c}$, then $k_{t}=1.1$ (for the right tributaries of the river Svicha).

The calculation of indicators of wastewater development intensity coming to the right tributaries of the Svicha River was carried out (Table 2).
Table 2. The results of the calculation of the indicator of the intensity of wastewater of OPGD "Dolynanaftogaz"

\begin{tabular}{|c|c|}
\hline Water body & $\begin{array}{c}n \\
\text { considering } \\
k_{V} \text { and } k_{t}\end{array}$ \\
\hline r. Turianka & 1.3 \\
\hline r. Sadzhava & 6.3 \\
\hline r. Lushchava & 2.1 \\
\hline
\end{tabular}

Summarizing the results of the study the scale of estimation of natural self-purification of surface waters from pollutants depending on the calculated indicator of intensity of dilution (n) of sewage which criteria are the account of speed of a river flow and a temperature mode is offered (Table 3 ). When establishing the range of values of $n$, the average value of the calculated indicator of the intensity of wastewater dilution for the studied rivers, which is 4 , was taken into account.

Table 3. Scale for assessing the natural self-purification of surface waters from pollutants

\begin{tabular}{|c|l|}
\hline Range of $\mathrm{n}$ values & Degree of self-cleaning \\
\hline$n<1$ & Low intensity \\
\hline $1<n<2$ & Low intensity \\
\hline $2<n<4$ & Medium intensity \\
\hline $4<n<6$ & Moderate \\
\hline$n>6$ & High intensity \\
\hline
\end{tabular}

According to the proposed scale of surface water assessment, the degree of self-purification of water for the right tributaries of the Svich River is determined within the influence of oil and gas companies:

Turianka River - low intensity $(\mathrm{n}=1.3)$;

Sadzhava River - high intensity $(\mathrm{n}=6.3)$;

Lushchava River is medium-intensive $(\mathrm{n}=2.1)$.

As a result, it was determined that the river Sadzhava has the greatest ability to natural self-purification, as the multiplicity of dilution of wastewater is 6.3 .

An emergency situation occurred within the territory of the oil and gas company (2017), as a result of which oil pollution of the Lushchava River occurred. Therefore, field studies of this area were conducted and 10 water samples were taken to study the self-purification properties of the Lushchava River from pollutants.

As a result of the analysis of the taken samples of water it is established that the value of concentration of oil products fluctuates within $3.5-8 \mathrm{mg} / \mathrm{dm}^{3}$ that in 70 160 times exceeds admissible norms (at maximum concentration limit of $0.05 \mathrm{mg} / \mathrm{dm}^{3}$ ) (Shkitsa et al, 2020). 
A regression analysis was performed, which proves the relationship between the content of petroleum products and the distance of their distribution in the Lushchava River.

Fisher's F-test was used to verify the significance of the relationship (Toms, Lesperance, 2003). The reliability of the relationship between the indicators is confirmed by the coefficient of determination $\left(D=r^{2}\right)$, which is 0.96 .

The functional dependence (Fig. 2) of the process of self-purification of surface water from petroleum products, which is described by the equation, was established:

$$
C(n)=(8-0.008 \cdot L) /(1-0.0007 \cdot L)
$$

where $C(n)$ - concentration of oil products, $\mathrm{mg} / \mathrm{dm}^{3}$; $L$ is the distance from the source of pollution, $\mathrm{m}$.

Based on the proposed level of self-purification of water, it was determined that at a distance of 1135 $\mathrm{m}$ the content of petroleum products within will reach the standard MPC.

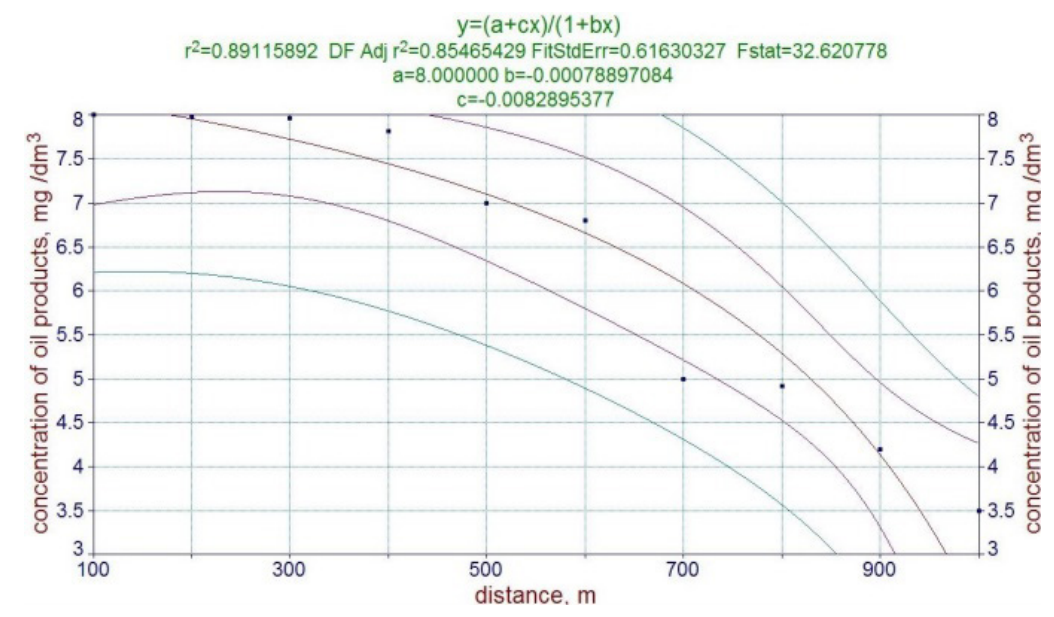

Fig.2. Functional dependence of surface water self-purification process on oil products

\section{Discussion.}

The presence of positive hydro-ecological potential, which, according to the authors, is directly proportional to the natural and man-made safety of the hydroecological environment and its components, determines the ability to restore its own structure and functions of hydro-ecosystems.

The balance of the hydrosphere is determined by the continuous cycle of matter and energy in all its components. The hydrosphere is an integral, selforganizing dynamic system (Rosenberg, Smelyansky 2005, Framework Directive 2000/60/EC "On the establishment of a framework for Community action in the field of water policy"). River hydroecosystems have the greatest ability to restore quickly their hydroecological potential.

The law of balanced nature management was first derived in 2000 by I. Yhnatov, A. Kokin (Yhnatov, 2000). Its content is as follows: in the transition to sustainable development, the rate of economic growth must be balanced with the rate of restoration of natural resources and the rate of restoration of the quality of the natural environment within the assimilation potential of nature (Arkhypova L, 2019, Kravchynskyi, 2021). According to the authors of the law, in the case of non-renewable resources, it is necessary to comply with the conditions of deductions for the replacement of other resources, with new properties that meet the requirements of advanced technology.

The application of the law of balanced nature management to natural-technogenic hydroecosystems components of the recreational environment, from the point of view of the authors may be as follows.

If within a separate natural and man-made hydroecosystem such a level of water use and water consumption is achieved due to the growth of water abstraction and "dirty" technologies, when the assimilation function of the recreational environment will not cope with the reproduction of resources and environmental quality (will not keep pace with economic growth inertia), there will be a need to maintain the quality and resource status of natural and man-made hydroecosystems through additional costs for its reproduction by reducing living standards. Further increase in the load on the recreational environment will be meaningless.

There are several scenarios.

The first scenario - to reduce the rate of water consumption, while reducing the rate of waste production, while maintaining "dirty" production to a level where the natural man-made hydroecosystem 
will cope with waste itself (fit the rate of economic growth in the rate of assimilation potential of nature), and the circulation of the substance will provide the quality of the recreational environment necessary for human existence. But then we need to "forget" about development, and even more sustainable.

The second scenario - to leave the rates (even small) of consumption of water resources satble in time, it will make possible to reduce waste and discharges due to improvement of production technologies. In this case, we can count on the time-limited potential for economic growth, as the problem of water scarcity arises again in the future.

The third scenario is to achieve compliance of economic growth rates with the rates of reproduction of quantitative and qualitative components of hydroecological safety. An imaginary balance is created, which contains a number of uncertainties. The first is what should be the marginal rate of economic growth? Second, from which state of the hydroecosystem should the implementation of the scenario of balanced development begin?

The fourth scenario includes the achievement of compliance of economic growth rates with the rate of reproduction of quantitative and qualitative indicators of water resources within the hydro-ecological potential of the hydro-ecosystem on the basis of natural and man-made safety of hydro-ecosystems. This is the only scenario that satisfies sustainable development models.

However, there is the question: how to estimate the value of the regenerative properties of hydroecosystems?

The second part of the article is devoted to the attempts to quantify the regenerative (self-purification) properties of natural and man-made hydroecosystems within the recreational environment of the Carpathian region with the available oil and gas production (Zasidko et al, 2020).

Oil and gas companies use large amounts of water in their production processes, which are reused or diverted to natural watercourses after treatment. Typically, companies control the quality of wastewater when discharged into rivers, as well as at a distance of 500 $\mathrm{m}$ above and $500 \mathrm{~m}$ below the discharge of wastewater. However, it is important to have information on the ecological condition of the river in general, potential sources of pollution and natural self-purification of surface waters. The main pollutants in the oil and gas industry are petroleum products.

Peculiarities of surface water pollution by oil products and self-purification of water from pollutants were studied by M. R. Maksymyuk et al. (2014), O. M. Krainyukov (2007), Gololobova, Dorogan, (2019), Rogowska et al (2020), Likhovid, E.G. et al.(2002), Malovanyy et al (2019), Bakar, Khalil, (2016), Survile, O.; Šaulys, V., Stanionyte, A. (2017), Tien
Zubaidah, Nieke Karnaningroem, Agus Slamet (2019), Aleksashkin, I.V., Pershina, E.D. ets.

The study of hydrochemical processes that occur in small rivers during the discharge of insufficiently treated return water is given much less attention than the study of water quality in large rivers. Since small rivers are a kind of "water capillaries", the quality of which depends on the ecological status of the entire river system, it is especially important to study the process of self-cleaning of small rivers within the influence of oil and gas industry.

The most important feature of surface runoff is the ability of the water flow to self-purification and the biological balance establishing. The process of selfpurification of watercourses is a very important natural phenomenon. Natural self-purification occurs due to biological, physical and chemical processes that lead to a decrease in the concentrations of pollutants. Mixing and dilution of pollutants to certain concentrations and their subsequent oxidation, destruction and transformation are the only mechanism of self-purification, and such processes are necessary components. Their joint action causes the "processing" of foreign substances and at certain loads eliminates their accumulation in the reservoir and maintaining the concentration below the permissible level (Kinash et al, 2019).

\section{Conclusions.}

Thus, the theoretical and practical aspects of the buffer capacity of the recreational environment of the Carpathian region of Ukraine by improving the assessment of self-purification on the example of natural and man-made hydroecosystems have been studed. The main factors influencing the natural process of selfpurification of natural watercourses are determined.

As a result of the study of water quality parameters of the right tributaries of the river Svicha, the maximal permissible concentration for the following pollutants was revealed: chlorides, ammonium salts, nitrites, ammonium nitrogen and biochemical oxygen consumption $\left(\mathrm{BOD}_{5}\right)$.

The intensity of wastewater dilution intensity has been improved by taking into account coefficients, the value of which depends on hydrometeorological factors, such as: river flow velocity and water temperature. A scale for assessing the natural self-purification of surface waters has been developed, which allowed to determine the degree of self-purification of the right tributaries of the Svicha River from pollutants: for Turianka (low intensity), Lushchava (medium intensity) and Sadzhava (high intensity).

Field researches of water quality of Lushchava river on the content of oil products as a result of emergency situation are carried out. Based on the laboratory analysis of the selected water samples, the content of oil 
products was exceeded by $70-160$ times in comparison with the standard of MPC $\left(0.05 \mathrm{mg} / \mathrm{dm}^{3}\right)$. The distance at which the content of oil products in the water of the Lushchava River reaches the maximum allowable concentration $(1135 \mathrm{~m})$ is calculated.

\section{References}

Arkhypova, L., Fomenko, N., Kinash, I and Golovnia, O., 2019. Territorial Recreational Systems and Sustainable Development. 7th Int. Conf. on Modeling, Development and Strategic Management of Economic System (MDSMES) Advances in Economics, Business and Management Research, Atlantis Press (99). 189-194.

Bakar, A.A.A., Khalil, M.K., 2016. Study on stream ability for self-purification process in receiving domestic wastewater. Adv. Sci. Lett. 22, 1252-1255. doi:10.1166/ as1.2016.6641

Bouman, D., 2014. Determination of potential of natural springs for water supply schemes. Retrieved from https://aquaforall.org/wp-content/uploads/2014/12/ Determination-of-potential-of-natural-springs publication_2014.pdf.

Chelmicki, W., Jokiel, P., Michalczyk, Z. and Moniewski, P., 2011. Distribution, discharge and regional characteristics of springs in Poland, 34(4), 244-256.

Eigen, M., Schuster, P., 2012. The hypercycle: a principle of natural self-organization, Springer Science \& Business Media, Reprint of papers which were published in: Die Naturwissenschaften, issues 11/1977, 1/1978, and 7/1978. doi:10.1007/978-3-642-67247-7

Gololobova, O., Dorogan, V., 2019. Ecological assessment of quality of surface water of small and medium rivers of Poltava region. Man and Environment. Issues of Neoecology, 31, 84-95. doi:10.26565/1992-42242019-31-08.

Gomelya, M., Shabliy, T., Radovenchyk, I., Overchenko, T., Halysh, V., 2019. Estimation of the Efficiency of Ammonia Oxidation in Anolyte of Two-Chamber Electrolyzer. Journal of Ecological Engineering, WNGB. doi:10.12911/22998993/105337

Hryniuk, V.I., 2018. Doslidzhennia protsesiv samoochyshchennia pravykh prytok richky Svichi baseinu Dnistra, Naukovyy Visnyk NLTU Ukrayiny [Research of processes of self-cleaning of the right tributaries of the river Svicha of the Dniester basin, Scientific Bulletin of UNFU of Ukraine], issue № 3 (28), 77-83 (in Ukrainian).

Karpets, K. M., 2014. Design factor relief-dependence selfcleaning permanent watercourses city of Kharkov. Man and Environment. Issues of Neoecology, 3-4 (22), 52-56. https://periodicals.karazin.ua/humanenviron/ article/view/1142

Karpinski, M., Pohrebennyk, V., Bernatska, N., Ganczarczyk, J., Shevchenko, O., 2018. Simulation of artificial neural networks for assessing the ecological state of surface water. International Multidisciplinary Scientific GeoConference Surveying Geology and Mining Ecology Management, SGEM, 18, 2.1: 693-700. doi:10.5593/ sgem2018/2.1/S 07.088
Thus, the pattern of self-purification of natural watercourses from oil products is obtained, which will allow making forecast maps of the buffer capacity of the recreational environment of the Carpathian region in case of emergency oil spills.

Khilchevskyi, V.K., Kurylo, S.M. and Sherstyuk, N.P., 2018. Chemical composition of different types of natural waters in Ukraine. Journal of Geology, Geography and Geoecology, 27(1): 68-80. doi:10.15421/111832

Kinash, I.P., Arkhypova, L.M., Polyanska, A.S., Dzoba, O.G., Andrusiv, U.Y. and Iuras, Iu. I., 2019. Economic evaluation of tourism infrastructure development in Ukraine. IOP Conf. Series: Materials Science and Engineering Volume International Conference on Applied Sciences 9-11 May 2018, Banja Luke, Bosnia and Herzegovina, 477, 012020. doi:10.1088/1757$899 \mathrm{X} / 477 / 1 / 012020$

Kinash, I., Shtogryn H., Sakal O., and Zapukhliak I., 2019. The ecologization of housing and communal services of Ukraine in the context of sustainable development, Journal of Eastern European and Central Asian Research, $6(1), 113-130$.

Krainiukov, O.M., 2007. Osoblyvosti rozpovsiudzhennia vuhlevodnevoho zabrudnennia ta otsinka yoho vplyvu na heoekolohichnyi stan baseinu r. Siverskyi Donets u mezhakh Kharkivskoi oblasti: avtoref. dys. kand. heohr. nauk [Peculiarities of hydrocarbon pollution distribution and assessment of its impact on the geoecological condition of the Seversky Donets river basin within the Kharkiv region: abstract of the dissertation of the candidate of geographical sciences], 20. (in Ukrainian).

Kravchynskyi, R.L., Korchemluk, M.V., Khilchevskyi, V.K., Arkhypova, L.M., Mykhailiuk, J. D., Mykhailiuk, I.R., 2021. Spatial-Factorial Analysis of Background Status of the Danube River State on the Northeastern Slops of the Ukrainian Carpathians. Journal of Physics: Conference Series, 1781(1), 012011

Krešić, N., Stevanović, Z., 2010. Groundwater Hydrology of Springs. Engineering, Theory, Management, and Sustainability. (Burlington, MA: ButterworthHeinemann, 2010). 592

Lykhovyd, E.H., Pershyna, E.D., Aleksashkyn, Y.V., 2002. Problemy modelyrovanyia protsessov samoochyshchenyia v pryrodnykh vodoemakh [Problems of modeling of processes of self-purification in natural reservoirs], 31, 274276. (in Russian).

Maksymiuk, M.R., Mitskevych, D.I., Mitskevych, A.I., 2014. Naftove zabrudnennia poverkhnevykh vod ta shliakhypodolannia yoho naslidkiv [Oil pollution of surface waters and ways to overcome its consequences], 233, issue 221, 37-40 (in Ukrainian).

Malovanyy, M., Moroz, O., Hnatush, S., Maslovska, O., Zhuk, V., Petrushka, I. and Sereda, A., 2019. Perspective Technologies of the Treatment of the Wastewaters with High Content of Organic Pollutants and Ammoniacal Nitrogen. Journal of Ecological Engineering, 20 (2), 8-15. doi:10.12911/22998993/94917 
Mandryk, O., Moskalchuk, N., Arkhypova, L., Pryhodko, M. and Pobigun O., 2020. Research quantitative indicators of the potential of solar energy in the Carpathian region of Ukraine IOP Conf. Series: Materials Science and Engineering, 749 012033. doi:10.1088/1757899X/749/1/012033

Mandryk, O., Arkhypova, L., Pukish, A., Zelmanovych, A. and Yakovlyuk, Kh., 2017. Theoretical and methodological foundations of sustainable development of Geosystems. IOP Conf. Series: Materials Science and Engineering, 200012018 . doi:10.1088/1757899X/200/1/012018

Odnorih, Z., Manko, R., Malovanyy, M., Soloviy, K., 2020. Results of Surface Water Quality Monitoring of the Western Bug River Basin in Lviv Region. Journal of Ecological Engineering, 21(3): 18-26. doi:10.12911/22998993/118303

Prykhodko, M., Arkhypova, L., Horal, L., Kozhushko, S., 2020. Concept of ecosystem services and its implementation in Ukraine. Journal of Geology, Geography and Geoecology, 36 (2). 68-80.

Rajchel, L., Czop, M., 2013. Walory źródeł karpackich wód mineralnych jako element przestrzeni publicznej. Uzdrowiska górskie i podgórskie [The values of Carpathian mineral water springs as an element of public space. Mountain and piedmont health resorts]. Szczawnica, Kraków, 8-9 November 2013 (in Polish).

Rogowska, J., Cieszynska-Semenowicz, M., Ratajczyk, W. and Wolska, L. 2020. Micropollutants in treated wastewater. Ambio, 49, 487-503. doi:10.1007/s13280 019-01219-5

Rosenberg, G.S., Smelyansky, I.E., 1997. Ekolohycheskyi maiatnyk (Smena paradyhm v sovremennoi ekolohyy), Zhurnal obshchei byolohyy [Ecological pendulum (paradigm shift in modern ecology), Journal of General Biology] 58, 4, 5-19 (in Russian).

Simkiv, L., Shults, S., Lutskiv, O., Andrusiv, U., 2021. Analysis of the dynamics of structural processes in the context of ensuring sustainable development. European Journal of Sustainable Development, 10 (1). 53-167

Shkitsa, L., Yatsyshyn, T., Lyakh, M., Sydorenko, O., 2020. Innovative approaches to the formation of environmental safety at the objects of oil and gas production. IOP Conf.
Ser.: Mater. Sci. Eng. 749, 012009. doi:10.1088/1757899X/749/1/012009

Shmandiy, V., Bezdeneznych, L., Kharlamova, O., Sviatenko, A., Malovanyi, M., Petrushka, K. and Polyuzhyn, I., 2017. Methods of salt content stabilization in circulating water supply systems. Chemistry \& Chemical Technology. 11(2): 242-246. doi:10.23939/ chcht11.02.242

Staśko, S., Buczyński, S., 2018. Drought and its effects on spring discharge regimes in Poland and Germany during the 2015 drought. Hydrological Sciences Journal, 63, 741-751. doi:10.1080/02626667.2018.1446215

Stevens, L.E., Springer, A.E. and Ledbetter, J.D., 2011. Inventory and Monitoring Protocols for Springs Ecosystems. http://docs.springstewardship.org/PDF/ Springs_Inventory_Protocols_110602.pdf

Survilè, O., Šaulys, V., Stanionytè, A., 2017. An assessment of self-purification of regulated and natural streams. In Proceedings of the $10^{\text {th }}$ International Conference Environmental Engineering, Vilnius, Lithuania, 27-28 April

Toms, Judith, D., Lesperance, Mary, L., 2003. Piecewise Regression: a Tool for Identifying Ecological Thresholds. Ecology. 84(8): 2034-2041. doi:10.1890/02-0472

Water Framework Directive 2000/60/EC. Retrieved from https:/ec.europa.eu/environment/water/waterframework/index_en.html.

Yhnatov, V.H., 2000. Puty obespechenyia rehyonalnoi ekolohycheskoi bezopasnosty v sbalansyrovannom pryrodopolzovanyy [Ways to ensure regional environmental safety in a balanced nature management]. 2, 17-27 (in Russian).

Zubaidah, T., Karnaningroem, N., Slamet, A., 2019. The Self-Purification Ability in The Rivers of Banjarmasin, Indonesia. Journal of Ecological Engineering, 20, issue 2, 177-182. doi:10.12911/22998993/97286

Zasidko, I., Polutrenko, M., Mandryk, O., Stakhmych, Y., Petroshchuk, N., 2019. Complex Technology of Sewage Purification from Heavy-Metal Ions by Natural Adsorbents and Utilization of Sewage Sludge. Journal of Ecological Engineering, 20 (5): 209-216. doi:10.12911/22998993/105576. 